\title{
The Integration of 21st-Century Learning Framework in the ASIE Instructional Design Model
}

\author{
Ismail Md Zain \\ Utusan Malaysia, National Media \\ Mainstream, Kuala Lumpur, \\ Malaysia
}

\author{
Balakrishnan Muniandy \\ University Sains Malaysia, \\ Penang, Malaysia
}

\author{
Wahid Hashim \\ Utusan Malaysia, National Media \\ Mainstream, Kuala Lumpur, \\ Malaysia
}

\begin{abstract}
Learning and innovation skills are the main features of the 21st-Century Learning Framework besides life and career skills as well as ICT skills. The 4Cs (critical thinking, communication, collaboration, and creativity) are the requirements in establishing "globally competitive learners". Thus, teachers need to design the instruction by the above needs in the current education landscape. An Integral ASIE Instructional Design Model (Ismail \& Balakrishnan, 2014; 2016) developed as an alternative solution to the questions on how do teachers design their instruction, what are the strategical approaches needed and how do teachers fulfill the need of their learners in the 21st-Century learning requirements. ASIE stand for "Analyze", "Strategize", "Implement" and "Evaluate". As an online planning model, it is interactive to the user, integrative in planning the content, prescriptive in the planning procedures and constructive in the organization of the components. This "learner-centered approach" in designing instruction provides a solution to the issues of individual differences giving equal opportunities to the learners in the learning process. The Model, which is accessible at www.asiemodel.com, has a planning mechanism known as Multiple Integration Worksheet (MIW) which guides teachers in the course of formulating and integrating the best possible practices in the instructional planning strategies at macro and micro levels. Workshops conducted, followed by 5 Likert Scales Questionnaires to find out teachers' views on the application of the model in the instructional planning process. Results show that teachers have positive views on the design of the model.
\end{abstract}

Keywords: instructional design, instructional design model, 21st-Century learning, learners' psychological profiles

\section{Introduction}

The Design of Instruction is an important feature in 21st-Century Teacher Education in fulfilling the needs of 4Cs (critical thinking, communication, collaboration, and creativity) developing "globally competitive learners" (Partnership for 21st Century Skills, 2008). Hence, instructional design models (ID) need to move from adopting a standard approach to developing models that have an impact on learners profiles, creating a much better learning experience, skills, and knowledge both in the classroom and online (Oblinger \& Oblinger, 2005).

Ismail Md Zain, Ph.D., Adviser, Education Department, Utusan Malaysia, National Media Mainstream. Balakrishnan Muniandy, Ph.D., professor, Centre for Instructional Technology \& Media, University Sains Malaysia. Wahid Hashim, Head of Education Department, Utusan Malaysia, National Media Mainstream. 
The move is towards a learner-centered approach in fulfilling the above needs. The Integral ASIE Instructional Design Model (Ismail \& Balakrishnan, 2016) developed serves as an alternative solution to the above challenges and requirements for schools and institutions of higher learning. ASIE stand for Analyze, Strategize, Implement and Evaluate (Figure 2). This "learner-centered approach" in designing instruction provides the solution to the issues of individual differences by giving equal opportunities to learners in the learning process as well as prepares and create awareness of the 21 st-Century knowledge and skills amongst teachers.

The 21st-Century Learning Framework (Partnership for 21st Century Skills, 2008) creates teachers the awarenessof learning components needed in establishing a more critical and creative learning environment for their learners. Moreover, the framework (Figure 1) provides elements preparing learners' readiness in their future employability in achieving the qualities needed in the workplace. Learners need learning and innovation skills such as critical thinking, communication, collaboration and creativity (4Cs) as mentioned above in the course of their studies on the core subjects selected.

\section{The 21st-Century Learning Framework}

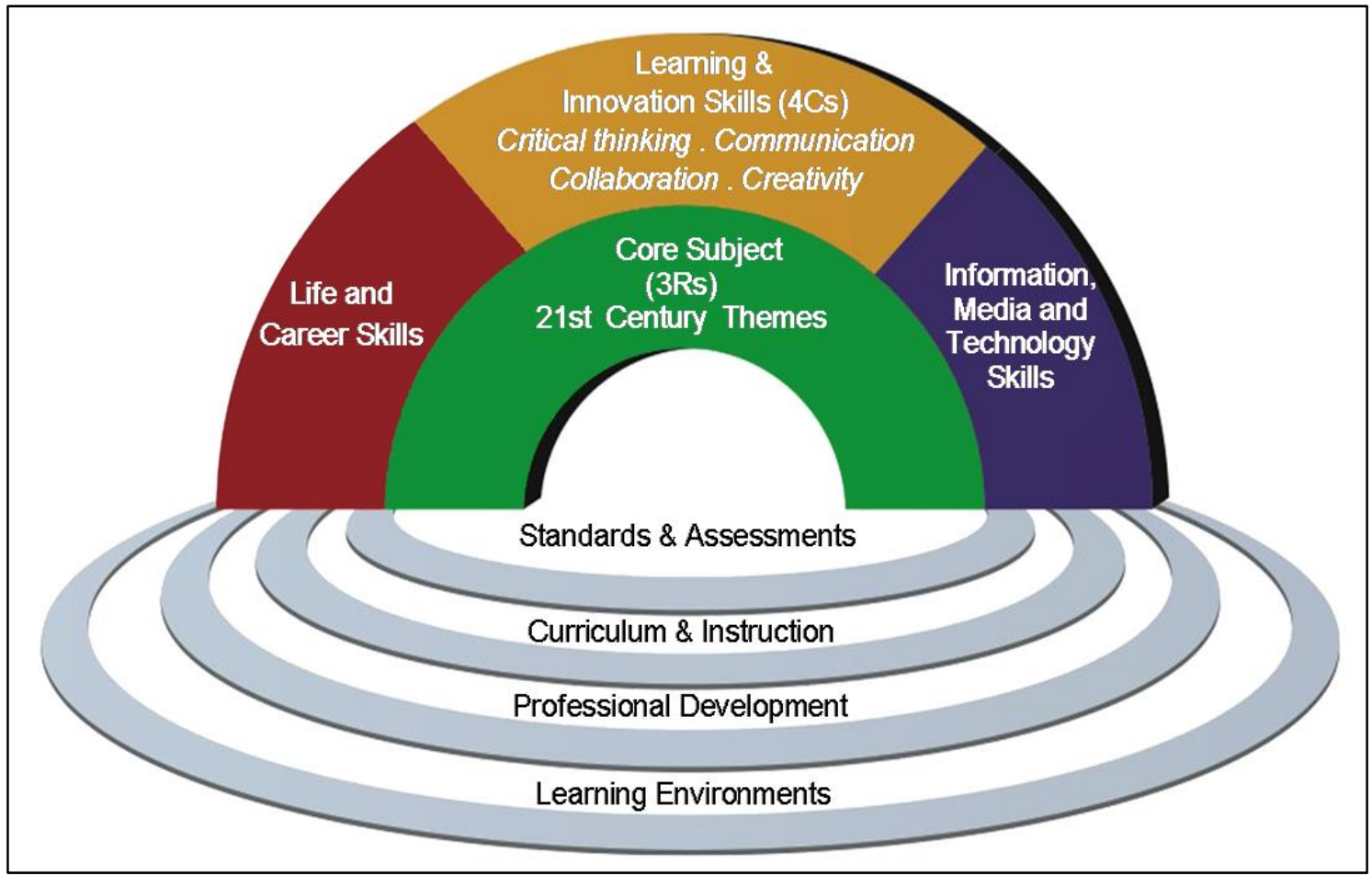

Figure 1. The 21st-Century learning framework (Image adapted from http://www.p21.org/).

New ideas, creating, creativity and problem solving are the keywords for various definitions of innovation which are related to the principle of $4 \mathrm{Cs}$ in the 21 st-Century learning features that are essential in preparing learners to be innovative. These learning and innovation skills have to be developed and nurtured, encouraging them to "think outside of the box", learning and developing new ideas. It is a challenge for teachers to formulate strategies in integrating those elements to broaden learners' knowledge as well as generating their minds in approaching and solving issues in the course of their studies (Ismail \& Balakrishnan, 2016). 
Those skills need to be developed by engaging them in the activities related to the 21 st-Century themes namely global awareness, financial, economic, business and entrepreneurial literacy, civic literacy, health literacy, and environmental literacy. Besides, learners need to a have a set of personal qualities such as flexibility and adaptability, initiative and self-direction, social and cross-cultural skills, productivity and accountability, leadership and responsibility which formed the life and career skills embedded in their learning. The ability to navigate complex life and work environments in the globally competitive information age requires learners to pay rigorous attention to developing adequate life and career skill.

The information, media, and technology skills are vital in transforming learners' minds through different approaches (Anderson \& van Weert, 2002). It is the ability to recognize when information is needed by the individual and have the capacity to locate, evaluate, and use effectively. Information literacy skills include accessing information efficiently, evaluating information critically, and using information accurately and creatively. These literacies form the basis for lifelong learning (Andretta, 2005).

\section{Research Questions}

The complexity of today's learning needs lead to the following research questions:

(1) How do teachers design their instruction according to the 21 st-Century learning framework?

(2) What are the strategical approaches needed in facing the 21st-Century learning and teaching challenges?

(3) How do teachers fulfill the need of their learners in establishing equal opportunities in gaining knowledge?

Teachers need to formulate strategies following the principles of an instructional design model. The Integral ASIE Instructional Design Model developed is a solution to those problems and fulfilling the 21st-Century learning framework.

\section{Research Methodology}

Detail information on ASIE Model was given to the 105 samples of teachers participating in the workshop followed by a hands-on experience on the operational aspect of the online ASIE Model, which last for three days. The 5 Likert Scale Questionnaires are given to the respondents to analyze their views on the Effectiveness of ASIE Model upon the instructional planning. Data showing the frequencies of respondents on the items of the questionnaires are analyzed and discussed.

\section{Theoretical Framework}

Theoretically, by looking at various perspectives, ASIE Model belongs to the paradigms of behaviorism, cognitivism, constructivism and connectivism. Unlike some of the conventional models that initially designed for Instructional System Development (ISD) (Seel, 1997; Gustafson \& Branch, 2002), ASIE is a classroom-based ID Models which follows the principles of instructional design. Theories of behaviorism, cognitivism, constructivism are the three broad learning theories most often utilized in the creation of instructional environments. These theories, however, were developed in a time when technology did not impact learning. Over the last twenty years, technology has reorganized how we live, how we communicate, and how we learn. Learning needs and theories that describe learning principles and processes should be reflective of underlying social environments. Vaill (1996) emphasizes that "learning must be a way of being - an ongoing set of attitudes and actions by individuals and groups that they employ to try to keep abreast of the surprising, 
novel, messy, obtrusive, recurring events" (p. 42).

New technology forces the 21 st-Century learner to process and apply information in a very different way and at a very different pace from any other time in history thus, lead to the emergence of connectivism. According to Siemens (2005), connectivism was driven by the understanding that decisions were based on rapidly altering foundations. New information is continually acquired, and the ability to draw distinctions between important and unimportant information is vital. Bartlett (1932) pioneered what became the constructivist approach (Good \& Brophy, 1990). Constructivists believe that learners construct their own reality or at least interpret it based upon their perceptions of experiences, so an individual's knowledge is a function of one's prior experiences, mental structures, and beliefs that are used to interpret objects and events. What someone knows is grounded in the perception of the physical and social experiences which are comprehended by the mind (Jonassen, 1991).

The Integral ASIE Instructional Design Model has fundamentally encompassed the philosophical attributes of metaphysics, epistemology, axiology, ethics and logic. These philosophical underpinnings strengthen the need for professional education player primarily classroom teachers to execute this model in their daily teaching and learning endeavors.

\section{Introduction to the Integral ASIE Instructional Design Model}

The Integral ASIE Instructional Design Model (Figure 2) served as a 21st-Century design tool for teachers. The features can be applied conventionally or in an online mode. ASIE is an acronym for Analyze, Strategize, Implement and Evaluate. It is an alternative solution to the above challenges for schools and institutions of higher learning. The model is concerned on learners' aspirations, emphasizing on the learning strategies, fulfill learners' learning requirements (learner-centered) in designing instruction. The application specifically towards accommodating, integrating, applying (strategizing) current educational needs, preparing learners for the 21st-Century learning environment, engaging and exploring students' potentials (the development of 4C) achieving "globally competitive personality". Most of the ID models originally designed for Instructional System Development (ISD), courseware development, selection of teaching materials and the development of teaching methods (Seel, 1997). They are more concern in teachers' delivering process in designing instruction (teacher-centered), answering the question "What the teachers should give or deliver?" (teachers' preparation). ASIE model answers the questions on "How the learners should engage, react and responds?" (learners' collaboration, communication, engagement, and interactions). The Model provides practical design procedures.

\section{The Operational Aspect of the Model}

The model encompasses of 4 major components with its aspects and items that would be able to customize by the user (see Table 1, Figure 2). The learner-centered approach is not just facilitating learners to learn at their own pace in the learning process, but it begins as early as in the designing process. The first component requires teachers to analyze the instructional profile, learners' profiles and instructional media profile. The formulation of learning objectives and learning outcomes in the instructional profile are important in determining learners' activities that based upon learner-centered approach. Items in the learners' profiles, such as multiple intelligences, learning styles, and other relevant profiles, need to be identified for the purpose of an appropriate selection of the best possible instructional media, resources and activities to cater the learners' needs as well as to provide equal opportunities in the learning process. 
Table 1

Structure of the Integral ASIE Instructional Design Model

\begin{tabular}{|c|c|c|c|c|}
\hline \multicolumn{2}{|c|}{ COMPONENT } & \multirow{2}{*}{$\begin{array}{l}\text { ASPECT } \\
\text { Instructional profile }\end{array}$} & \multirow{2}{*}{\begin{tabular}{|l} 
ITEM \\
Subject, theme, learning areas, topic, etc. \\
Learning outcomes/ learning objectives etc.
\end{tabular}} & \multirow{5}{*}{$\begin{array}{l}\text { MIW } \\
\text { Multiple } \\
\text { Integration } \\
\text { Worksheet } \\
\text { (MIW) is an } \\
\text { overall planning } \\
\text { mechanism or } \\
\text { framework based }\end{array}$} \\
\hline \multirow{3}{*}{ A } & \multirow{3}{*}{ Analyze } & & & \\
\hline & & Learners' profiles & $\begin{array}{l}\text { Multiple intelligences, learning styles in relation to their age } \\
\text { group/clusters, etc. }\end{array}$ & \\
\hline & & $\begin{array}{l}\text { Instructional media } \\
\text { profile }\end{array}$ & $\begin{array}{l}\text { Types of media chosen elements } \\
\text { Compositions }\end{array}$ & \\
\hline \multirow{5}{*}{$\mathbf{S}$} & \multirow{5}{*}{ Strategize } & $\begin{array}{l}\text { Integrating-instructional } \\
\text { media }\end{array}$ & $\begin{array}{l}\text { Instructional media chosen for the lesson in relation to the } \\
\text { above profiles }\end{array}$ & \\
\hline & & Accommodating-skills & 21st-Century Learning skills and features & components, \\
\hline & & Applying-tools & $\begin{array}{l}\text { Applying various thinking tools-Higher Order Thinking } \\
\text { Skills (HOTS) } \\
\text { Instructional tools_- technique, methods, activities, etc. }\end{array}$ & $\begin{array}{l}\text { used to guide } \\
\text { instructors/ } \\
\text { teachers in } \\
\text { formulating \& }\end{array}$ \\
\hline & & Instilling-values & Element of moral values \& others & integrating the \\
\hline & & Formulating & Instructional questions & best possible \\
\hline \multirow[b]{2}{*}{ I } & \multirow[b]{2}{*}{ Implement } & Adapting & Adapting for lesson/course development & practices in the \\
\hline & & Applying & $\begin{array}{l}\text { Applying in the learning \& teaching process based upon } \\
\text { lesson/course plan developed }\end{array}$ & instructional \\
\hline \multirow{3}{*}{$\mathbf{E}$} & \multirow{3}{*}{ Evaluate } & Responding & Responding to the feedback & $\begin{array}{l}\text { strategies } \\
\text { to meet the }\end{array}$ \\
\hline & & Reviewing & $\begin{array}{l}\text { Reviewing the instructional planning strategies for } \\
\text { improvement }\end{array}$ & \multirow{2}{*}{$\begin{array}{l}\text { to meet the } \\
21 \text { st-Century } \\
\text { learning needs } \\
\text { and requirements } \\
\text { for learners. }\end{array}$} \\
\hline & & Revising & $\begin{array}{l}\text { Revising the instructional planning strategies for future } \\
\text { redesigning }\end{array}$ & \\
\hline
\end{tabular}

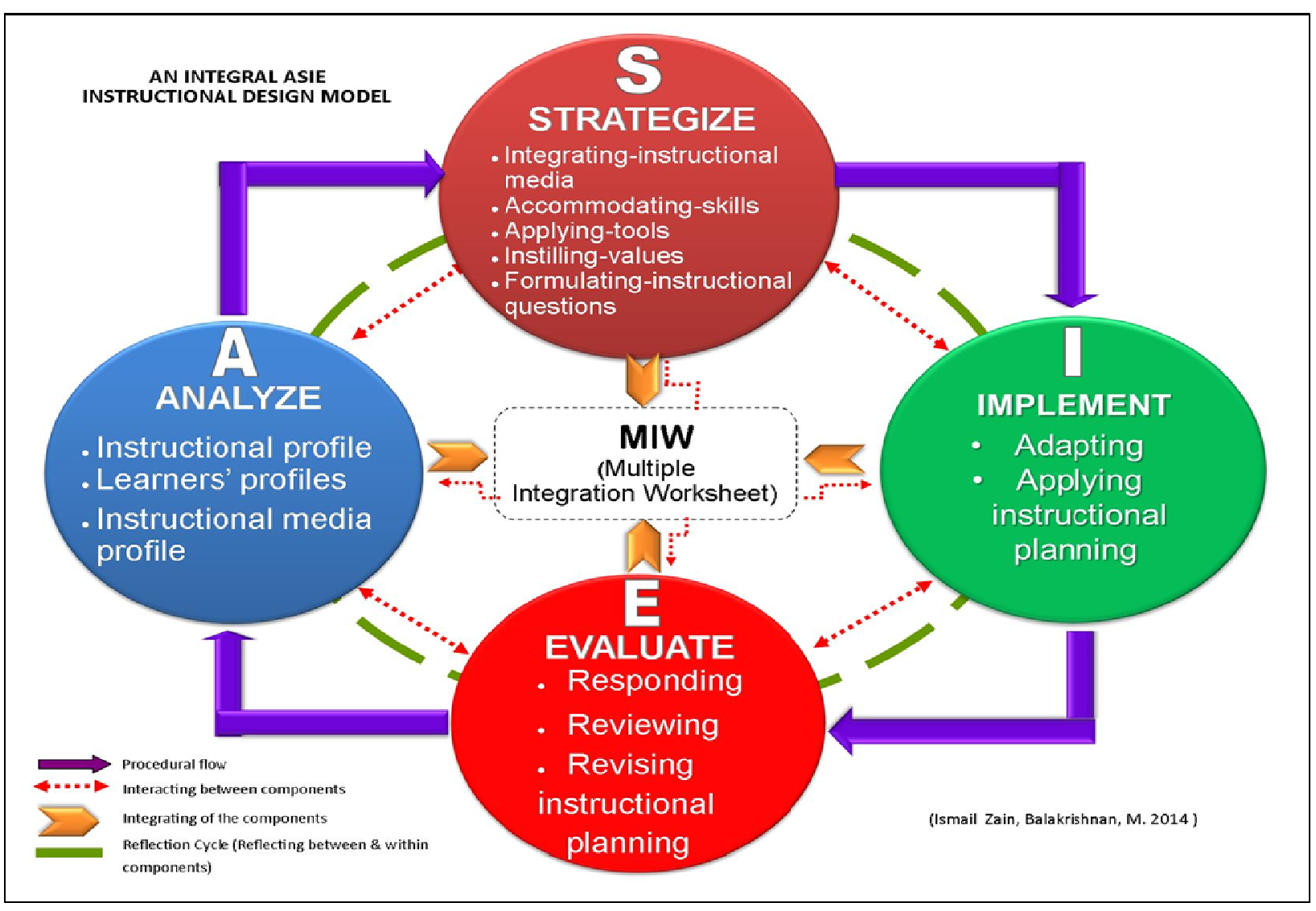

Figure 2. An integral ASIE instructional design model. 
After analyzing and identifying the items in the first component, teachers need to strategize their planning according to the learning needs and requirements. Items in the second component of the model play a significant role in engaging learners in the "learner-centered approach". It provides solutions in integrating instructional media, accommodating all features of the 21st-Century learning skills, applying various instructional tools (techniques, methods, activities) (Newby et al., 2000), and appropriate thinking tools especially dealing with the principle of higher order thinking skills (HOTS) and instilling moral values.

The final item in the component is the formation of instructional questions that based upon items in the first and second component of the model. They are essential questions developed for the topic selected which formed instructional strategies driving learners in the learning activities. It also serves as a means of evaluating their performances (formative evaluation) in the activities engaged. In the online planning mode, all information gathered, selected, constructed from the main component and finally integrated into the instructional planning mechanism or framework known as Multiple Integration Worksheet (MIW) mentioned above. It served as guidelines for instructors or teachers to develop their instruction at the macro (overall planning) or micro level (several daily lesson plans for a topic or unit selected). It is interactive since it enables editing at the respective items. It may be kept in the digital form or produce in hard copy. Table 2 and Table 3 show MIW that displays elements of the first and second component only while the third and fourth component are invisible since those components are the procedural flow for instructors or teachers to put their instructional planning into classroom and evaluation purposes. However, being an interactive and constructive model, those components guide users to amend their work for redesigning purposes by activating MIW into editing mode when users click on any aspect of the component.

The third component of the model is the implementation stage where the designed instruction is applied in the classroom either at a macro or a micro level. At this stage instructors' or teachers' daily course or lesson plan is developed and adapted based upon MIW. Improvising may take place to ensure its appropriateness and effectiveness on the learners in the learning and teaching environment. The final component is the evaluation stage whereby responses from feedback are gathered to review and revised the instructional planning strategies in the respective component and aspect of the model. It is a reflection process for future instructional redesigning opportunities. However, evaluation is not only taking place at the end of the planning but every component while the planning is in progress. The indictions areby the dotted lines and arrows where ever applicable.

Table 2

Multiple Integration Worksheet (MIW)

\begin{tabular}{|c|c|c|c|c|c|c|c|}
\hline \multicolumn{3}{|l|}{ Analyze } & \multicolumn{5}{|l|}{ Strategize } \\
\hline $\begin{array}{l}\text { Instructional } \\
\text { profile }\end{array}$ & \begin{tabular}{|l} 
Learners' \\
profiles
\end{tabular} & $\begin{array}{l}\text { Instructional } \\
\text { media profile }\end{array}$ & Integrating & Accommodating & Applying & Instilling & Formulating \\
\hline $\begin{array}{l}\text { Class : } \\
\text { Subject: } \\
\text { Theme: } \\
\text { Learning area: } \\
\text { Topic: } \\
\text { Learning } \\
\text { objective (s): } \\
\text { Learning } \\
\text { outcome (s): }\end{array}$ & $\begin{array}{l} \\
\text { Learning } \\
\text { Styles } \\
\text { Multiple } \\
\text { intelligences }\end{array}$ & $\begin{array}{l}\text { Types of } \\
\text { media: } \\
\text { Elements: } \\
\text { Composition }\end{array}$ & $\begin{array}{l}\text { Instructional } \\
\text { media: }\end{array}$ & $\begin{array}{l}\text { 21st-Century } \\
\text { learning skills: } \\
\text { Thinking } \\
\text { skills: }\end{array}$ & $\begin{array}{l}\text { Thinking } \\
\text { tools: } \\
\text { Methods/ } \\
\text { techniques } \\
\text { activities }\end{array}$ & Values & $\begin{array}{l}\text { Instructional } \\
\text { questions } \\
\text { Activities based } \\
\text { on LOTS } \\
\text { Activities based } \\
\text { on HOTS }\end{array}$ \\
\hline
\end{tabular}


Table 3

Descriptions of Multiple Integration Worksheet

\begin{tabular}{|c|c|c|c|c|c|c|c|}
\hline \multicolumn{3}{|l|}{ ANALYZE } & \multicolumn{5}{|c|}{ STRATEGIZE } \\
\hline $\begin{array}{l}\text { Instructional } \\
\text { profile }\end{array}$ & $\begin{array}{l}\text { Learners' } \\
\text { profiles }\end{array}$ & $\begin{array}{l}\text { Instructional } \\
\text { media profile }\end{array}$ & Integrating & Accommodating & Applying & Instilling & Formulating \\
\hline $\begin{array}{l}\text { Class : } \\
\text { Subject: } \\
\text { Theme: } \\
\text { Learning area: } \\
\text { Topic: } \\
\text { Learning } \\
\text { objective(s): } \\
\text { Learning } \\
\text { outcome(s): }\end{array}$ & $\begin{array}{l}\text { Learning } \\
\text { Styles } \\
\text { (examples: } \\
\text { visual, } \\
\text { kinesthetic } \\
\text { etc.) } \\
\text { Multipleintelli } \\
\text { gences } \\
\text { (examples: } \\
\text { musical, } \\
\text { naturalist etc.) } \\
\text { or } \\
\text { other form of } \\
\text { learners' } \\
\text { psycho-logica } \\
\text { l profiles such } \\
\text { as } \\
\text { psycho-metric } \\
\text { test, etc }\end{array}$ & \begin{tabular}{|l} 
Types of \\
media: \\
Information \\
from web-site, \\
social media, \\
graphic, \\
learning \\
objects (LO), \\
audio/video \\
clips, \\
animationsetc.) \\
Elements: \\
(examples: \\
graphic \\
video, \\
audio, \\
Composition \\
Object- \\
building/seas \\
Background, \\
mountain \\
ranges \\
Emotion: \\
feeling \\
towards \\
surrounding
\end{tabular} & $\begin{array}{l}\text { Instructional } \\
\text { media: } \\
\text { Strategies } \\
\text { developed to } \\
\text { integrate } \\
\text { instructional } \\
\text { media in } \\
\text { learning) } \\
\text { (example: } \\
\text { students } \\
\text { watching } \\
\text { video clip } \\
\text { followed by } \\
\text { interaction } \\
\text { session to } \\
\text { generate } \\
\text { critical \& } \\
\text { creative } \\
\text { minds or } \\
\text { students } \\
\text { discuss } \\
\text { information } \\
\text { from } \\
\text { web-site, } \\
\text { social } \\
\text { media etc.) }\end{array}$ & \begin{tabular}{|l|}
21 st-Century \\
learning skills: \\
Learning skills to \\
be integrated into \\
the lesson. \\
(examples: global \\
awareness, \\
creativity, \\
collaboration etc.) \\
Thinking skills: \\
(example: \\
analyzing, \\
creating from \\
revised Blooms' \\
Taxonomy)
\end{tabular} & $\begin{array}{l}\text { Thinking tools: } \\
\text { (to generate } \\
\text { students' } \\
\text { critical \& } \\
\text { creative minds } \\
\text { towards HOTS } \\
\text { (example: cause } \\
\text { \& effect/ CAF, } \\
\text {-from de } \\
\text { Bono's work, } \\
\text { mind maps, } \\
\text { graphic } \\
\text { organizers etc.) } \\
\text { Methods/ } \\
\text { techniques } \\
\text { activities } \\
\text { cooperative \& } \\
\text { collabo-rative } \\
\text { learning, } \\
\text { drama-tization, } \\
\text { etc. }\end{array}$ & $\begin{array}{l}\text { Values } \\
\text { moral values } \\
\text { that need to be } \\
\text { instilled } \\
\text { examples } \\
\text { loving, caring, } \\
\text { esprit de } \\
\text { corps- } \\
\text { feelings of } \\
\text { loyalty, } \\
\text { enthusiasmetc.) }\end{array}$ & $\begin{array}{l}\text { Instructional } \\
\text { questions } \\
\text { Activities based } \\
\text { on LOTS } \\
\text { Activities based } \\
\text { on HOTS } \\
\text { (Teachers' } \\
\text { expectation \& } \\
\text { reflections } \\
\text { towards } \\
\text { students } \\
\text { learning } \\
\text { outcomes and } \\
\text { activities). }\end{array}$ \\
\hline
\end{tabular}

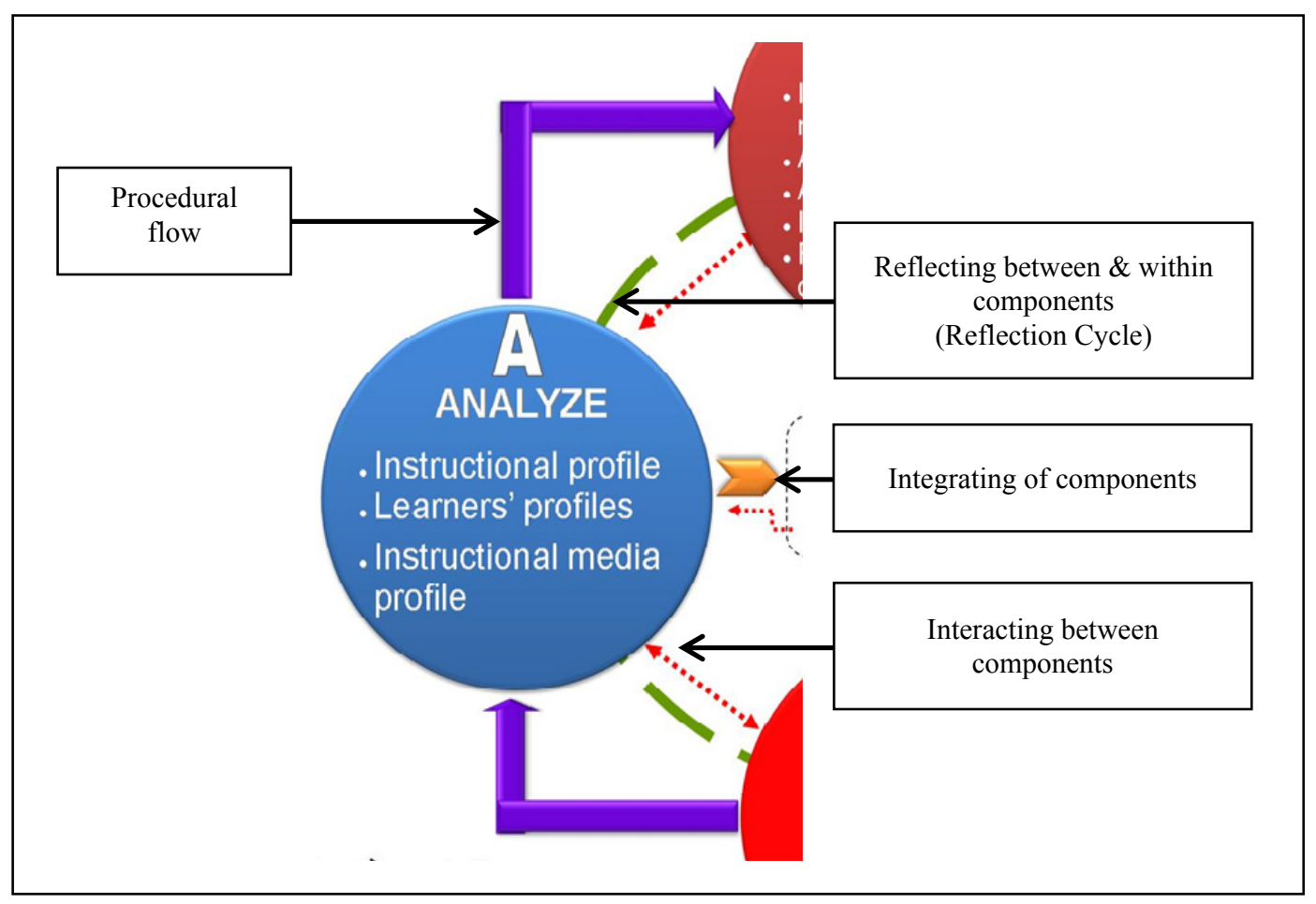

Figure 3. Lines and arrows. 
Lines, arrows and a reflection cycle in the model signify the multiple interactions of teachers in the process of considering, identifying and selecting the best possible strategies or practices engaging learners in the learning activities as indicated in the learner-centered learning principles.

\section{Impact of the Model}

\section{Technological Based Instructional Design Model}

Unlike the traditional model, ASIE Model provides users an accessible to the technology in designing their instruction. The Multiple Integration Worksheet (MIW) is not a part of the system model but is embedded to form a planning mechanism. These unique features guide instructors and teachers in the process of formulating and integrating multiple elements from the model for the best possible practices in the instructional design and planning strategies at the macro or micro level in an online environment.

\section{Provides Communication and Sharing of Ideas}

It provides communication and sharing of thoughts to teachers through MIW in the borderless world. It is efficient since it has been structured accordingly to the needs the current educational environment. It provides flexibility in designing items - allows customization with regards to their own instructional practices in the current situation. The model provides learners to unleash their potentials establishing global personalities in a globally competitive workplace for their futures employment opportunities. It is cost-effective in providing and enhancing knowledge and skills for teachers.

\section{Establishing Unlearn, Learned and Relearn Society}

The model provides room for learners (educationist) to learn different approaches in educational designing. Relearn of new strategies formulated in respond to the changes in educational landscape, and unlearn the past experiences through the transformation process. The model creates the awareness of the importance and impact of current innovation in ID towards the 21st-Century education, establishing a better future living for the next generation.

\section{Provides Continuous Professional Development Process}

The model portrays a new approach to instructional design that needs educators to learn formally in a Continuous Professional Development (CPD) programs. In informal education, it works through conversation, exploration and enlargement of experience and guidance by their colleagues. It also gives opportunities for the non-formal situation in learning which is flexible, learner-centered, contextualized and uses a participatory approach promoting life-long learning for knowledge and personal growth since it is accessible in the online mode of designing instruction.

Figure 4 illustrates the integration of 21st-Century learning framework into the model designing items in the first and second component. The arrows indicate the relationship between features of 21 st-Century learning framework and items constructed in the ASIE Model fulfilling all requirements in the 21st-Century learning. Thus, the design of instruction follows the right path to its final destination - the 21st-Century learning environment. 
The Integration of 21st-Century Learning Framework

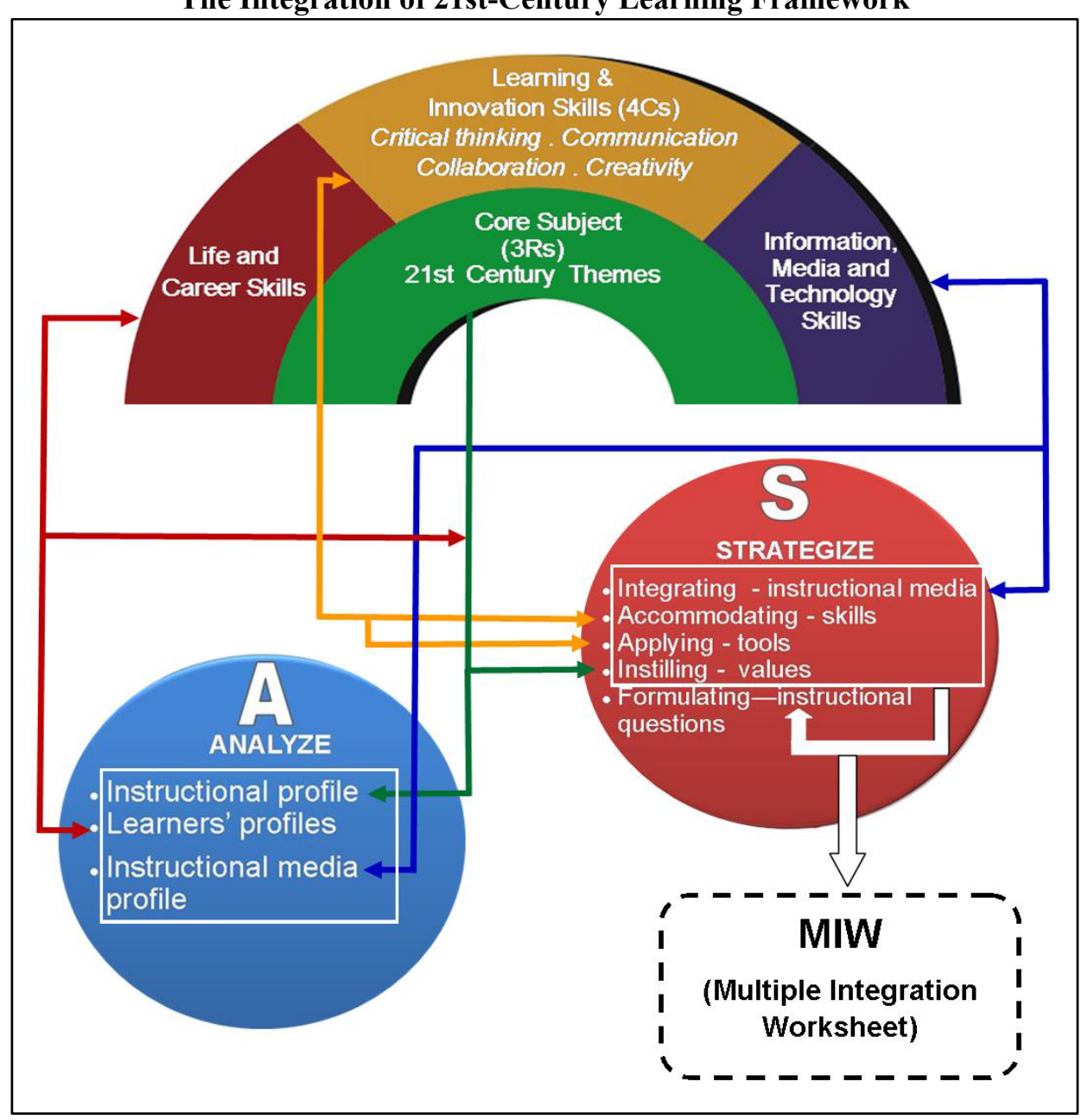

Figure 4. The integration of the 21st-Century learning framework in ASIE model.

Findings, Discussion, and Conclusion

By looking at Table 4 , the scores clearly show that all items are above $50 \%$ on the strongly agree column (Clarity-65\%, Relevancy-75\%, Usefulness-65.83\%, Improvement of knowledge and skills-73.33\%, Fosters "learner-centered" approach-72.50\%).

On this premise, this study indicates that The Integral ASIE Instructional Design Model is significant for teachers designing their lesson. Aimed at establishing learners' engagement in the learning environment, this learner-centered model prepares students to develop their intellectual capacity holistically that allow them to succeed in the 21st-Century learning with all the opportunities and challenges existed. The innovation of ICT application in the classroom has tremendously expanded. Thus teachers, as well as other educators, must have the knowledge and skills to integrate ICT, content knowledge, and pedagogical knowledge effectively into the learning environment (Mishra \& Koehler, 2006). If not, students will not be exposed to the wealth of information resources available and will be prevented from learning to use ICT effectively (Anderson \& Glenn, 2003). The Model is the solution to the above issues in the field of designing instructions which answered all the three stated research questions. 
Table 4

Analysis of the Effectiveness of an Integral ASIE ID Model

\begin{tabular}{|c|c|c|c|c|c|c|c|c|c|c|c|c|}
\hline \multirow[t]{3}{*}{ Items } & \multicolumn{10}{|c|}{ Frequencies/percentage } & & \\
\hline & \multicolumn{3}{|c|}{ Strongly agree } & \multicolumn{2}{|l|}{ Agree } & \multicolumn{2}{|l|}{ Neutral } & Disagree & \multicolumn{2}{|c|}{$\begin{array}{l}\text { Strongly } \\
\text { disagree }\end{array}$} & \multicolumn{2}{|c|}{ Total } \\
\hline & $f$ & $\%$ & $f$ & $\%$ & $f$ & $\%$ & $f$ & $\%$ & $f$ & $\%$ & $N$ & $\%$ \\
\hline Clarity & 78 & 65.00 & 35 & 29.17 & 7 & 5.83 & 0 & 0.00 & 0 & 0.00 & 120 & 100 \\
\hline $\begin{array}{l}\text { Relevance to } 21 \text { st-Century } \\
\text { learning environment }\end{array}$ & 90 & 75.00 & 25 & 20.83 & 5 & 4.17 & 0 & 0.00 & 0 & 0.00 & 120 & 100 \\
\hline $\begin{array}{l}\text { Useful for instructional } \\
\text { planning }\end{array}$ & 79 & 65.83 & 30 & 25.00 & 11 & 9.17 & 0 & 0.00 & 0 & 0.00 & 120 & 100 \\
\hline $\begin{array}{l}\text { Improvement of knowledge } \\
\text { and skills among teachers }\end{array}$ & 88 & 73.33 & 22 & 18.33 & 10 & 8.33 & 0 & 0.00 & 0 & 0.00 & 120 & 100 \\
\hline Fosters "learner-centered" & 87 & 72.50 & 15 & 12.50 & 10 & 8.33 & 8 & 6.67 & 0 & 0.00 & 120 & 100 \\
\hline
\end{tabular}

\section{References}

Andrews, D. H., \& Goodson, L. A. (1981). A comparative analysis of models of instructional design. In G. J., Anglin (1981) (Ed.). Instructional technology: Past, present, and future. Englewood, Colorado: Libraries Unlimeted, Inc.

Anderson, J., \& Glenn, A. (2003). Building capacity of teachers/facilitators in technology-pedagogy integration for improved teaching and learning. Bangkok, UNESCO Regional Office for Education in Asia and the Pacific. Retrieved 20 May, 2016, from http://www.unescobkk.org/fileadmin/user_upload/ict/e- books/ ICT Building Capacity /BuildingCapacity.pdf.

Anderson, J., \& van Weert, T. (Eds). (2002). Information and communication technology in education: A curriculum for schools and programme of teacher development. Paris, UNESCO. Retrieved 20 May, 2016, from http://unesdoc.unesco.org/images/0012/001295/129538e.pdf

Andretta, S. (2005). Information literacy: A practitioner's guide. Oxford, U.K.: Chandos Publishing, Ltd.

Good, T. L., \& Brophy, J. E. (1990). Educational psychology: A realistic approach (4th ed.). White Plains, N.Y.: Longman

Gustafson, K. L., \& Branch, R. M. (2002). What is Instructional Design? In R. A. Reiser, \& J. V. Dempsey (Eds.), Trends and issues in instructional design and technology. Upper Saddle River, N.J.: Merrill Prentice Hall.

Ireland, T. (2007). Situating connectivism. Retrieved November 7, 2008, from http://design.test.olt.ubc.ca/Situating_Connectivism

Ismail, M. Z. (2012). Best practices of ICT integration strategies for teaching and learning: An approach to generate critical and creative minds. Paper presented at 2012 Rome European Academic Conference \& Mediterranean Cruise Program, 6-8 Jun 2012. Also available in Journal of Teaching and Education, 2(3), 79-86. UniversityPublications.net.

Ismail, M. Z. (2013). Instructional media integration strategies for basic development of human capital: An approach to generate critical and creative minds in teaching and learning process. The Macrotheme Review, 2(2) 55-64 (Spring 2013 : AMultidisciplinary Journal of Global Macro Trends: Special Issue On Education And Training).

Ismail, M. Z., \& Balakrishnan, M. (2014). An integral ASIE instructional design model: Towards higher order thinking skill in designing instruction. Paper presented at the National Conference on the Development of Higher Order Thinking Skill, 14-16 April 2014, Kinta Riverfront Hotel, Ipoh Perak. Examination Council, Malaysia Ministry of Education.

Ismai, M. Z., \& Balakrishnan, M. (2016). ASIE instructional design model for the 21st Century learning: An integrated approach in instructional designing for teachers. Saarbrucken, Deutschland. Germany: Scholar's Press.

Ismail M. Z., Balakrishnan., M., \& Wahid, H. (2016). An integral ASIE ID model: The 21st Century instructional design model for teachers. Universal Journal of Educational Research4, 3, 547-554,. DOI: 10.13189/ujer.2016.040311

Jonassen, D. H. (1991). Objectivism versus constructivism: Do we need a new philosophical paradigm? Educational Technology Research and Development, 39(3).

Mishra, P., \& Koehler, M. J. (2006). Technological pedagogical content knowledge: A framework for teacher knowledge. Teacher College Record, 108, 1017-1054.

Newby, T. J. et al. (2000). Instructional technology for teaching and learning. New Jersey: Prentice Hall.

Oblinger, D. G., \& Oblinger, J. L. (2005). Educating the Net Generation. Retrieved July 25th, 2015, from http://www.educause.edu/educatingthenetgen 
Partnership for 21st Century Skills. (2008). A report and mile guide for 21st Century skills. Retrieved September 10, 2008, from Http://www.21stCenturyskills.org/downloads/P21_Report.pdf

Seel,. N. M. (1997). Model of instructional design: Introduction and overview. In R. D. Tennyson, F. Schott, N. Seel, \& S. Dijkstra (Eds.), Solving instructional design problems, instructional design: International perspective (Vol. 1, pp. 355-360). Mahwah, N.J.: Lawrence Erlbaum.

Siemens, G. (2005, January). Connectivism: A learning theory for the digital age. International Journal of Instructional Technology \& Distance Learning, Retrieved November 03, 2008, from http://www.itdl.org/Journal/Jan_05/article01.htm

Vaill, P. B., (1996). Learning as a way of being. San Francisco, C.A.: Jossey-Blass Inc. 